\title{
A Comparative Study of DNA Cleavage Ability of Copper(II)-Schiff Base-Polypyridyl Complexes
}

\author{
Dr. Addla Shilpa*1 \\ Assistant Professor, Department of Chemistry, Mahatma Gandhi Institute of Technology (MGIT), Hyderabad, India ${ }^{1}$.
}

\begin{abstract}
A tridentate Schiff base ligand (saltrp/saltyr) was synthesized by coupling salicylaldehyde (sal) with amino acid - tryptophan (trp) and tyrosine (tyr). $\mathrm{Cu}$ (II) Complexes with salicylidene amino acid Schiff base and polypyridyl ligands i.e [Cu(II)(saltrp)(phen)] (1), [Cu(II)(saltrp)(bipy)] (2), [Cu(II)(saltyr)(phen)] (3) and [Cu(II)(saltyr)(bipy)] (4) (where phen $=1,10$ phenanthroline and bipy $=2,2$ ' bipyridine) were synthesized, characterized by various techniques and structures were proposed. Complexes display a square pyramidal geometry around $\mathrm{Cu}(\mathrm{II})$ with Schiff base coordinating through ONO donor atom and polypyridyl ligands through NN donor atoms. CT-DNA (Calf Thymus) binding studies for complexes (1-4) display an intercalative mode of binding with binding affinity of order 1>2>3>4. Since Small metal complexes that promote hydrolytic cleavage of DNA are useful in molecular biology and drug design, an attempt is made in this article to compare the DNA cleavage abilities of complexes 1-4 reported earlier and to analyze the reasoning for affinity towards DNA cleavage. The hydrolytic DNA cleavage activity of these complexes was studied by gel electrophoresis and DNA cleavage rate constant were determined. Phenanthroline complexes $(\mathbf{1}, \mathbf{3})$ binds and cleaves DNA more effectively as compared to their corresponding bipyridine $(\mathbf{2}, \mathbf{4})$ analogues due to the presence of extended aromatic phenyl ring which might be involved in an additional stacking interaction with DNA bases. Comparison among the amino acid systems revealed that tyrosine schiff base complexes $(\mathbf{3}, \mathbf{4})$ show better DNA cleavage than tryptophan analogues $(\mathbf{1}, \mathbf{2})$ and the DNA cleavage ability follow the order : $\mathbf{3}>\mathbf{4}>\mathbf{1}>\mathbf{2}$.
\end{abstract}

Keywords: Amino acids, Schiff bases, Copper complexes, DNA cleavage, kinetics.

\section{INTRODUCTION}

DNA is usually referred as molecule of heredity for genetic propagation of all qualities. The positive charge on most metals can interact with the negative charge of the phosphate backbone of DNA. Since DNA is the primary target for many drugs, binding between DNA and metal complexes can be used to study interaction of drugs with DNA and help in designing new metallonucleases. Cleavage of supercoiled (SC) DNA into nicked circular forms (NC) and linear forms are necessary biological process. Mimicking such a process in the laboratory is important for design of new drugs [1,2]. Metal complexes can cleave the DNA through three types of mechanisms, which are hydrolytic, oxidative and photolytic cleavages [3, 4].

\section{Role of Copper}

Among transition metal complexes, $\mathrm{Cu}(\mathrm{II})$ complexes have attracted much interest as DNA binding and cleavage agents owing to their high reactivity, coordinating abilities and biological importance. Many $\mathrm{Cu}(\mathrm{II})$ complexes have been synthesized as artificial nucleases [5-8].

\section{Role of Schiff base in DNA cleavage}

Schiff base ligands are regarded as the most promising ligands as they possess different coordinating atoms. Schiff base ligands and their complexes show higher biological activities such as antimicrobial, antiviral, anticancer, antioxidant, DNA binding and DNA cleavage [9-17].

\section{Role of 1,10 Phenanthroline and 2,2' Bipyridine in DNA cleavage}

Transition metal complexes of polypyridyl ligands like phen, bipy or their modified variants are widely employed in studies of DNA in view of their applications in several research areas including bioinorganic and biomedicinal chemistry $[18,19]$

Copper complexes containing phen bases have received considerable current interest in the nucleic acids chemistry due to their various applications following the discovery of the "chemical nuclease" activity of bis-phen complex of $\mathrm{Cu}(\mathrm{l})$ in presence of $\mathrm{H}_{2} \mathrm{O}_{2}$ and a reducing agent by Sigman and coworkers [20-22].

Considering the significance of $\mathrm{Cu}(\mathrm{II})$ complexes, schiff base complexes and heterocyclic bases in the design of artificial nucleases, we have made an attempt in this article to analyze and compare the DNA cleavage abilities of amino acid 
Vol. 8, Issue 4, April 2021

DOI: $10.17148 /$ IARJSET.2021.8466

based schiff base complexes reported from our laboratory. Complexes studied in the present article are a combination of biologically significant metal ion, copper; a tridentate salicylidene amino acid schiff base ligand (saltrp, saltyr); polypyridyl ligands (phen, bipy) with varying intercalating ability.

\section{MATERIALS}

General: Chemicals and solvents (Spectroscopic grade) required for the synthesis of ligands and complexes were purchased from Sigma and other commercial sources. Supercoiled (SC) plasmid pUC19 DNA for DNA cleavage study and Tris $-\mathrm{HCl}$ buffer were obtained from Bangalore Genei (India).

\section{EXPERIMENTAL}

\section{A. Synthesis and Characterization of Metal Complexes}

$\mathrm{Cu}$ (II)-salicylidene amino acid Schiff base complexes with heterocyclic bases (1-4) reported from our laboratory [23,24] were synthesized by adopting a method published earlier with changes [25] (Scheme 1).

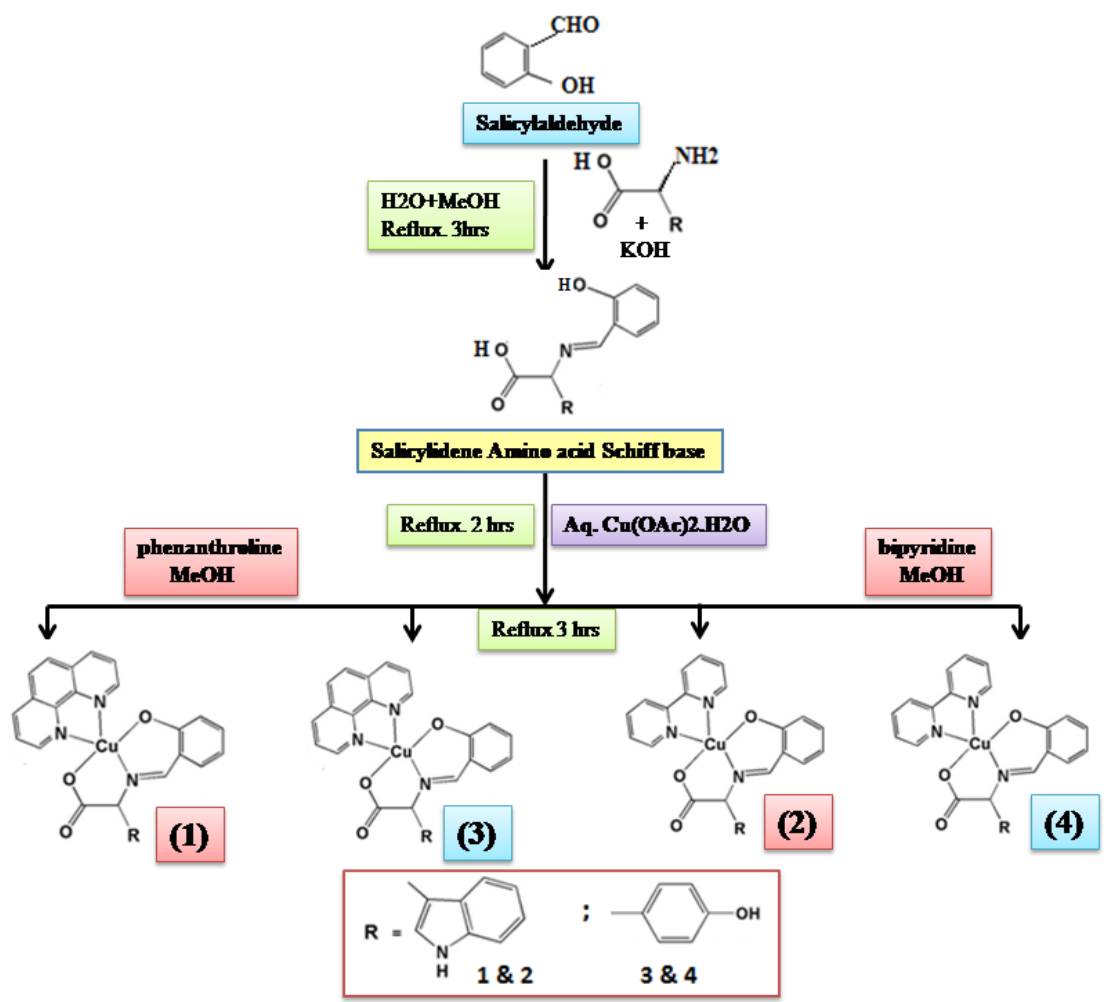

Scheme 1. Synthesis of complexes 1-4

Complexes (1-4) were characterized by elemental analyses, Conductivity measurements, Magnetic moment and spectroscopic techniques like ESI-MS, IR and UV-Vis spectroscopy. The analytical data for the complexes were in good agreement with the proposed molecular formulae.

Based on the results obtained from characterization data, structures were proposed for complexes 1-4. Molecular structures for 1-4 show a square pyramidal geometry around $\mathrm{Cu}(\mathrm{II})$ with Schiff base (saltrp/saltyr) coordinating as ONO donor ligand and heterocyclic base (phen/bipy) coordinating as NN donor ligand. Green single crystals of $[\mathrm{Cu}(\mathrm{II})$ (saltrp)(bipy)] (2) were grown by slow evaporation of methanolic solution of $\mathbf{2}$ for a week and was structurally characterized by single crystal X-ray crystallography [23].

\section{B. DNA Binding and Cleavage Study}

CT-DNA binding studies for complexes 1-4 with CT-DNA were carried by various techniques viz. absorption spectroscopy, Thermal denaturation, fluorescence spectroscopy and viscosity. The DNA binding mode and affinity was established based on the results obtained.

DNA cleavage ability of 1-4 and kinetics of DNA cleavage was investigated by agarose gel electrophoresis and reported $[23,24]$. 


\section{International Advanced Research Journal in Science, Engineering and Technology}

Vol. 8, Issue 4, April 2021

DOI: $10.17148 / I A R J S E T .2021 .8466$

\section{RESULTS, DISCUSSION AND COMPARISION}

The DNA binding and cleavage activity of complexes [Cu(II)(saltrp)(phen)] (1), [Cu(II)(saltrp)(bipy)] (2), $[\mathrm{Cu}(\mathrm{II})(\mathrm{saltyr})(\mathrm{phen})](\mathbf{3}),[\mathrm{Cu}(\mathrm{II})(\mathrm{saltyr})($ bipy)$)(\mathbf{4})$ have been reported from our laboratory $[23,24]$. A brief summary about DNA binding mode and ability; a comparative study of DNA cleavage ability of 1-4 with the reasoning is made in this article.

\section{A. DNA Binding}

DNA binding mode and binding affinity of the complexes 1-4 was studied by various spectroscopic techniques confirmed that complexes 1-4 bind to CT-DNA via an intercalative mode of binding that involves a stacking interaction between the aromatic chromophore of the complex and base pairs of DNA [26]. Based on the trends obtained in binding studies, it can be inferred that DNA binding affinity for complexes follow the order $1>2>3>4$.

\section{B. DNA Cleavage}

Gel electrophoresis is a widely used technique [27-30] for monitoring DNA cleavage as it provides information regarding the percentage of cleavage as a function of concentration of nuclease (DNA cleaving agent). Hydrolytic cleavage, which started in a modest way of converting SC (supercoiled) DNA to the NC (Nicked circular) form, is now being used for identifying the $\%$ of cleavage at different concentrations of complexes thereby helping in studying their DNA cleavage abilities. The cleavage reaction on SC pUC19 DNA by $\mathrm{Cu}(\mathrm{II})$ complexes 1-4 were monitored by agarose gel electrophoresis and reported $[23,24]$. In general, when DNA is subjected to gel electrophoresis, a relatively fast migration will be observed for the intact SC DNA. Scission on one strand (nicking), relaxes SC DNA to generate slower moving $\mathrm{NC}$ form. Scission on both strands generates a linear form that migrates between SC form and NC form. Incubation of DNA with increasing concentration of the 1-4 reported [23, 24] has shown degradation of SC DNA to the NC form (Scheme 2). The cleavage efficiency was found to increase with increase in the concentration of $\mathrm{Cu}$ (II) complexes (Fig. $1)$.

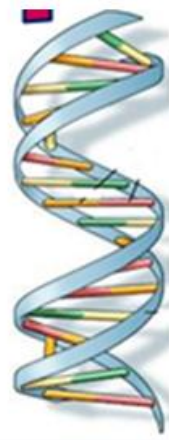

Super coiled (SC) DNA

\section{Complexes 1-4}

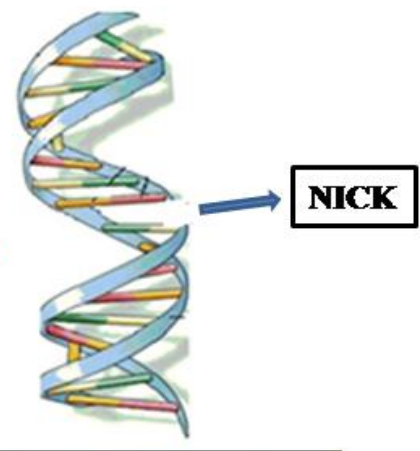

Nicked Circular (NC) DNA

Scheme 2: Schematic representation of degradation of supercoiled (SC) DNA into Nicked circular (NC) form on interaction of Complexes (1-4).

(a)

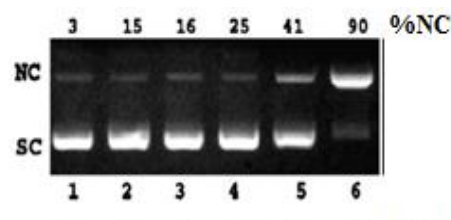

(b)

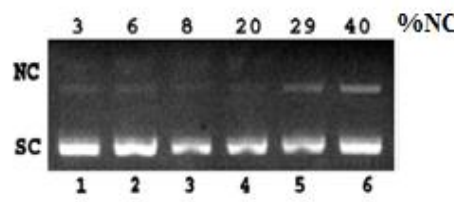

(c)

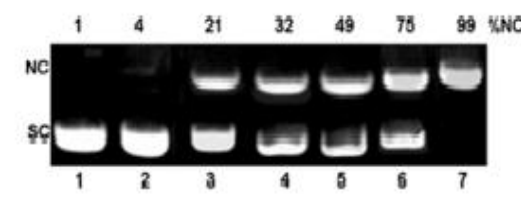

(d)

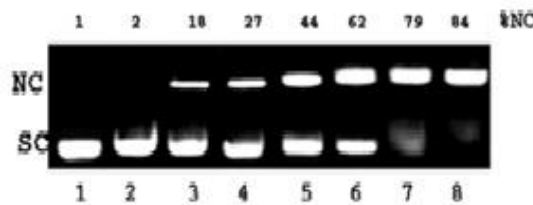

Fig. 1 Hydrolytic cleavage of SC pUC19 DNA at $37^{\circ} \mathrm{C}$ in $5 \mathrm{mM}$ Tris. $\mathrm{HCl} / 5 \mathrm{mM} \mathrm{NaCl}$ buffer by complexes 1-4.

(a) Lane 1, DNA control; Lane 2, DNA+1 $(50 \mu \mathrm{M})$; Lane 3, DNA+ $1(100 \mu \mathrm{M})$; Lane 4, DNA+ $1(150 \mu \mathrm{M})$; Lane 5, DNA+ $1(200 \mu \mathrm{M})$; Lane 6, DNA+ $1(250 \mu \mathrm{M})$; (b) Lane 1, DNA control; Lane 2, DNA+ $2(50 \mu \mathrm{M})$; Lane 3, DNA+ 2 $(100 \mu \mathrm{M})$; Lane 4, DNA+ $2(150 \mu \mathrm{M})$; Lane 5, DNA+ $2(200 \mu \mathrm{M})$; Lane 6, DNA+2 $(250 \mu \mathrm{M})$; (c) Lane 1, DNA control; Lane 2, DNA +3 $(25 \mu \mathrm{M})$; Lane 3, DNA + $3(50 \mu \mathrm{M})$; Lane 4, DNA + $3(75 \mu \mathrm{M})$; Lane 5, DNA + $3(100$ $\mu \mathrm{M})$; Lane 6, DNA $+3(125 \mu \mathrm{M})$; Lane 7, DNA $+3(150 \mu \mathrm{M})$. (d) Lane 1, DNA control; Lane 2, DNA + $4(25$ 
Vol. 8, Issue 4, April 2021

DOI: $10.17148 /$ IARJSET.2021.8466

$\mu \mathrm{M})$; Lane 3, DNA + $4(50 \mu \mathrm{M}) ;$ Lane 4, DNA + $4(75 \mu \mathrm{M}) ;$ Lane 5, DNA + $4(100 \mu \mathrm{M}) ;$ Lane 6, DNA + $4(125$ $\mu \mathrm{M})$; Lane 7, DNA + $4(150 \mu \mathrm{M})$; Lane 8, DNA + $4(200 \mu \mathrm{M})$.

Table I depicts the cleavage efficiency of complexes 1-4 and few similar salicylidene amino acid schiff base complexes. The data from the table clearly establishes the higher efficiency of tyrosine schiff base complexes $3 \& 4$ in DNA cleavage over tryptophan schiff base complexes 1 \& $\mathbf{2}$. It can be noticed here that tryptophan complexes display a higher DNA binding ability over tyrosine complexes and follow the order $\mathbf{1}>\mathbf{2}>\mathbf{3}>\mathbf{4}$ (as inferred from DNA binding studies), while tyrosine schiff base complexes display a higher DNA cleavage ability over tryptophan schiff base complexes and follow the order 3>4 $>\mathbf{1}>\mathbf{2}$ (Fig. 2). It can be observed here that DNA binding affinity order and DNA cleavage ability order is different for complexes 1-4. The enhanced cleavage activity of tyrosine complexes $(3 \& 4)$ over tryptophan analogues $(\mathbf{1} \& \mathbf{2})$ is due to effective hydrogen bonding of ' $\mathrm{OH}$ ' group present in the side chain of tyrosine than ' $\mathrm{NH}$ ' group present in the side chain of tryptophan with the phosphate group of DNA backbone.

TABLE I. Hydrolytic DNA Cleavage Data for Complexes.

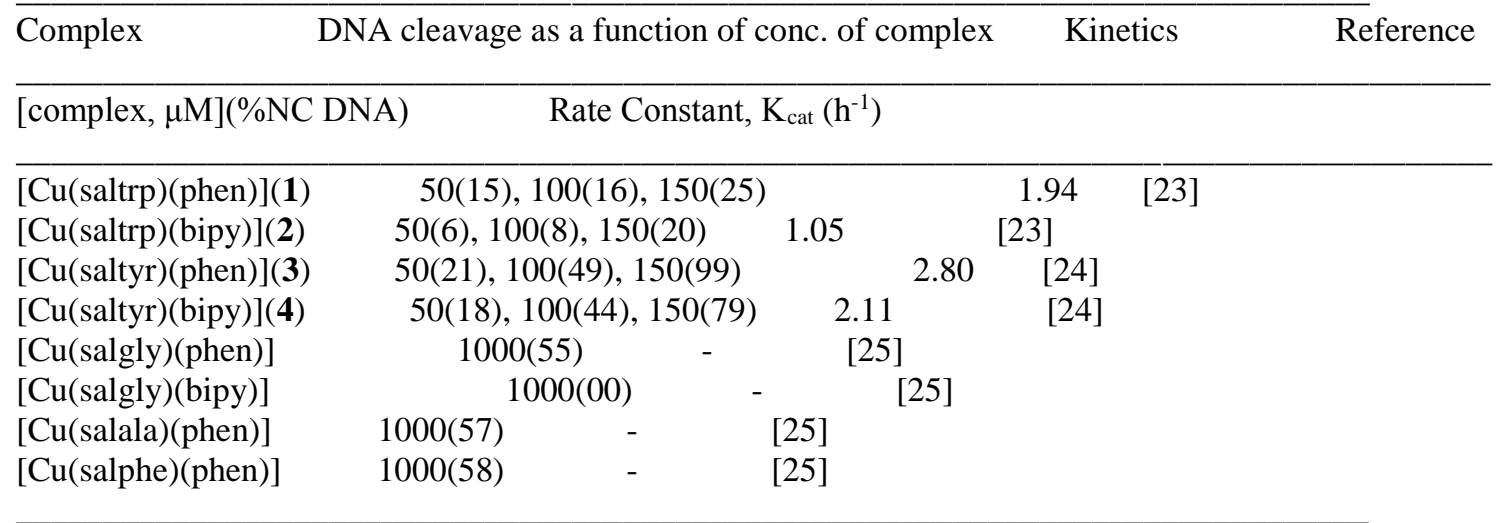

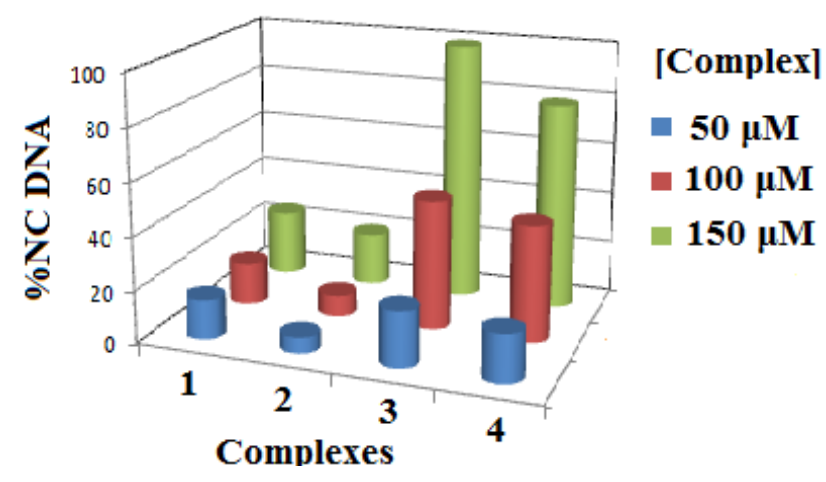

Fig. 2 Bar diagram representing percentage of DNA cleavage efficiencies for 1-4 at a complex concentration of 50, 100 and $150 \mu \mathrm{M}$ showing an increase in \%NC DNA with increase in complex concentration.

Comparison of DNA cleavage efficiency of Complexes 1-4 with similar complexes of glycine, alanine and phenylalanine schiff bases [25] (Table 1) infer that 1-4 have a better cleavage ability over relative amino acid schiff base complexes. Saltrp complexes are showing a higher DNA cleavage activity over salgly, salala, salphe systems owing to the presence of extended aromatic ring in tryptophan which helps in effective DNA binding and thereby enhanced DNA cleavage ability. saltyr complexes are showing an enhanced cleavage ability over other systems due to the presence of ' $O H$ ' group in tyrosine which is involved in hydrogen bonding with the DNA backbone.

Kinetic aspects of DNA cleavage were also studied and reported for 1-4 [23,24] by monitoring the \% cleavage vs. incubation time (Fig. 3). Hydrolysis rate constants $\mathrm{K}_{\text {cat }}$ for the conversion of SC DNA to NC DNA calculated by curve fitting at fixed $\mathrm{Cu}(\mathrm{II})$ concentration of complexes $(500 \mu \mathrm{M})$ are $1.94 \mathrm{~h}^{-1}$ for $1,1.05 \mathrm{~h}^{-1}$ for $2,2.80 \mathrm{~h}^{-1}$ for 3 and $2.11 \mathrm{~h}^{-1}$ for 4 (Table 1). Order of hydrolysis rate constant values for $\mathbf{1 - 4}$ i.e. $\mathbf{3}>\mathbf{4}>\mathbf{1}>\mathbf{2}$ is consistent with the results obtained from DNA cleavage ability order by gel electrophoresis technique. 


\section{International Advanced Research Journal in Science, Engineering and Technology}

Vol. 8, Issue 4, April 2021

DOI: $10.17148 / I A R J S E T .2021 .8466$

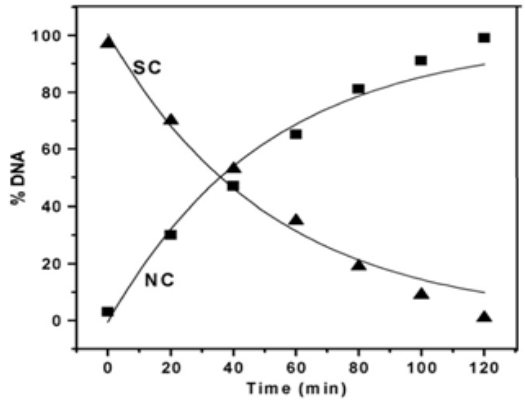

(a)

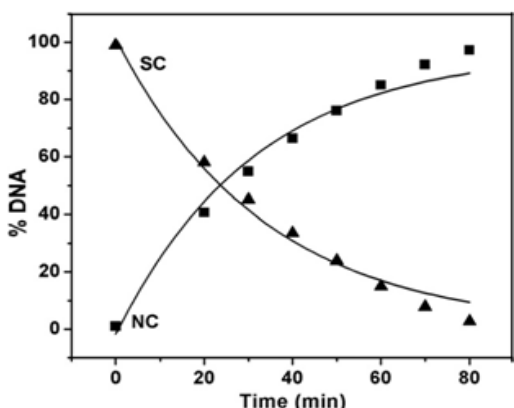

(b)

Fig. 3 Time course of DNA cleavage affected by 1 (a) and 3 (b). Data points ( $\boldsymbol{\Delta})$ refer to SC DNA and ( $\boldsymbol{\square})$ refer to NC DNA.

\section{CONCLUSIONS AND FUTURE SCOPE}

Transition metal complexes have been widely used to synthesize metallohydrolases capable of duplicating the function of endonucleases and to design \& develop DNA binding and cleavage agents. Copper(II) complexes are one of the most studied transition metal complexes as they are promising alternatives to cis platin as anticancer drugs. Owing to the importance of $\mathrm{Cu}$ in pharmacology, in this article we have presented a comparison of DNA cleavage abilities of $\mathrm{Cu}$ (II) amino acid schiff base complexes with heterocyclic bases reported from our laboratory. $\mathrm{Cu}(\mathrm{II})$ complexes 1-4 with salicylidene amino acid schiff base (saltrp, saltyr) and polypyridyl ligands (phen, bipy) were synthesized and characterized. DNA binding study by various techniques revealed that complexes bind to DNA by intercalative mode and binding affinity follows the order of $1>2>3>4$. DNA cleavage study by gel electrophoresis displays the efficient cleavage ability of complexes and follows the order $\mathbf{3}>\mathbf{4}>\mathbf{1}>\mathbf{2}$. Tryptophan schiff base complexes display a higher DNA binding ability over tyrosine schiff base complexes due to the extended ring size of amino acid i.e trp which enhances stacking interaction with DNA. In contrast tyrosine schiff base complexes display a higher DNA cleavage ability over tryptophan schiff base complexes due to the effective involvement of ' $\mathrm{OH}$ ' group of tyrosine in DNA phosphodiester bond hydrolysis. Future interest of work lies in the development of transition metal complexes with new planar Schiff bases which helps in effective DNA binding and thereby efficient DNA cleavage.

\section{REFERENCES:}

[1] R. Huang, A Wallqvist and D.G. Covell, Biochem. Pharm, 2005, vol. 69, p.1009.

[2] I. Kostova, Curr. Med Chem -AntiCancer Agents, 2005, vol. 5, p. 591.

[3] R. P. Sinha and D. P. Hader, UV-induced DNA damage and repair: a review Photochem. Photobiol. Sci. 2002, vol. 1, p. 225.

[4] C. J. Burrows and J. G. Muller, Oxidative Nucleobase Modifications Leading to Strand Scission Chem. Rev., 1998, vol. 98 p. 1109.

[5] D. K. Chand, H. J. Schneider, J. A. Aguilar, F. Escarti, E. Garcia-Espan and S. V. Luis, Inorg Chim Acta, 2000, vol. 316, p. 71.

[6] D. Y. Kong, J. Reibenspies, J. G. Mao, A.Clearfield and A. E. Martell, Inorg Chim Acta, 2003, vol. 342, p. 158.

[7] G. N. De Luliis, G. A. Lawrance and S. Fieuw-Makaroff, Inorg Chem Commun, 2000, vol. 3, p. 307.

[8] J-H. Li, J-T. Wang, L - Y. Zhang, Z - N. Chen, Z - W. Mao a n d L - N . Ji, J Coord Chem, 2009, vol. 62, p. 1775.

[9] O.A. El-Gammal, G.A. El-Reash, S.F. Ahmed, J. Mol. Struct. 2012, vol. 1, p.1007.

[10] L. Puccetti, G. Fasolis, D. Vullo, Z.H. Chohan, A. Scozzafava, C.T. Supuran, Bioorg. Med. Chem. Lett., 2005 , vol. 15 , p. 3096.

[11] J. Nawrot-Modranka, E. Nawrot, Acta Pol. Pharm., 2007, vol. 63, p. 429.

[12] C. Anitha, C.D. Sheela, P. Tharmaraj, S. Johnson Raja, Spectro-chim. Acta A. 2012, vol. 98 , p. 35.

[13] J. Wang, Z.Y. Yang, X.Y. Yi, B.D. Wang, J. Photochem. Photo biol., A. 2009, vol. 201, p. 183.

[14] S.A. Elsayed, I.S. Butler, B.J. Claude, S.I. Mostafa, Transit. Metal Chem., 2015, vol. 40, p. 179.

[15] Y. Li, Z. Yang, J. Coord. Chem. 2010, vol. 63, p. 1960.

[16] M. Grazul, E. Budzisz, Coordin. Chem. Rev. 2009, vol. 253, p. 2588.

[17] Y. Li, Z.Y. Yang, J. Fluoresc. 2010, vol. 20, p. 329.

[18] L-N. Ji, X-H. Zou and J-G. Liu, Coord Chem Rev, 2001, vol. 216/217, p. 513.

[19] N. A. P. Kane-Maguire and J. F. Wheeler, Coord Chem Rev, 2001, vol. 211, p. 145.

[20] D. S. Sigman, A. Mazumder and D. M. Perrin, Chem Rev, 1993, vol. 93, p. 2295.

[21] D. S. Sigman, D. R. Graham, V. D. Aurora and A. M. Stern, J Biol Chem., 1979, vol.254,p.12269.

[22] D. S. Sigman, T. W. Bruce, A. Mazumder and C. L. Sutton, Acc Chem Res, 1993, vol. 26, p. 98.

[23] P. R. Reddy, A. Shilpa, N. Raju, P. Raghavaiah, "Journal of Inorganic Biochemistry", 105, (2011), 1603.

[24] P. R. Reddy, A. Shilpa, "Polyhedron", 2011, vol. 30, p. 565.

[25] P.A.N. Reddy, M. Nethaji, A.R. Chakravarthy, "European Journal of Inorganic Chemistry", 2004, vol. 7, p. 1440.

[26] J.M. Kelly, A. B. Tossi, D. J. McConell, C. OhUigin, Nucleic Acids Res. 1985, vol. 13, p. 6017.

[27] S. A. Patil, V. H. Naik, A. D. Kulkarni, U. Kamble, G. B. Bagihalli and P. S. Badami, J Coord Chem, 2010 , vol. 63 , p. 688.

[28] P. R. Reddy and P. Manjula, J Chem Sci,, 2007, vol. 119, p. 603.

[29] P. R. Reddy, K. S. Rao and B . Satyanarayana, Tetrahed Letts., 2006, vol. 47, p. 7311.

[30] P. R. Reddy, S. K. Mohan, P. Manjula and T. K. Chakraborty, Chem Biodiv, 2006, vol. 3, p. 456. 